\title{
ORGANIC AND INORGANIC REMEDIATIONS OF CONTAMINATED SOILS WITH HEAVY METALS RESULTED FROM SOME ANTHROPOGENIC AVTIVITIES
}

\author{
Ibrahim M.A. Hegazi, Hassan H. Abbas*, Ashraf A. Mohamed \\ and Gamal F.O. El-Sheikh \\ Soils, Water and Environ. Res. Inst., Agric. Res. Center, Giza, Egypt \\ * Soils Dept., Fac. of Agric., Benha University, Egypt
}

\section{ABSTRACT:}

Soils can naturally reduce mobility and bioavailability of heavy metals as they are retained in soil by sorption, precipitation and complexation reactions. These natural processes can be accelerated by addition of some soil amendments, which converting the soluble forms to more geochemical stable solid phases. Hence, the current study represents a trial towards ameliorating soils polluted with heavy metals resulted from some anthropogenic activity. To achieve this target, in situ an incubation experiment was executed on two soil samples taken from El-Gabal El-Asfar farm (Qalubia Governorate) and El-Saff (Giza Governorate), subjected to heavy metals pollution due to irrigating with sewage effluent and industrial wastes, respectively. The studied two soils were mixed thoroughly in pots of $200 \mathrm{~g}$ soil capacity with some soil amendments, i.e., poultry manure, organic compost and bentonite at a rate of 2 $\%$, then the pots were daily wetted wit distilled water to reach a constant moisture content (field capacity) and incubated under room temperature at different periods of $0,25,50$ and 75 days.

Soil samples were taken to identify the effective role of the applied soil amendments throughout the different incubation periods, however, the values of EDTA-extractable $\mathrm{Ni}, \mathrm{Co}$ and $\mathrm{Cd}$ were determined. The most important obtained results could be summarized in the following:

1. EDTA-extractable amounts of $\mathrm{Ni}, \mathrm{Co}$ and $\mathrm{Cd}$ showed a progressively decreased in both amended soils with poultry manure, with a more effective role by increasing time of incubation period. The removed amounts of the studied metals for both investigated soils followed the descending order: $\mathrm{Ni}>$ $\mathrm{Co}>\mathrm{Cd}$. Also, the removal capacity of poultry manure seemed a highest figure with $\mathrm{Ni}$, lowest with $\mathrm{Co}$ and intermediate with $\mathrm{Cd}$.

2. Application of organic compost led to minimize the value of EDTAextractable $\mathrm{Ni}, \mathrm{Co}$ and $\mathrm{Cd}$ in both soils under study. The adsorbed amounts of these metals in El-Gabal El-Asfar soil exceeded obviously the corresponding ones in El-Saff soil. This trend was emphasized by the removal capacity of the compost for $\mathrm{Ni}, \mathrm{Co}$ and $\mathrm{Cd}$, which was recorded higher values in El-Gabal ElAsfar soil than in El-Saff one.

3. Values of EDTA-extractable $\mathrm{Ni}, \mathrm{Co}$ and $\mathrm{Cd}$ from both the bentonite amended soils also showed progressively decreased with increasing the incubation period. The absolute adsorbed amounts of $\mathrm{Ni}$ were the highest, whereas those of $\mathrm{Co}$ and $\mathrm{Cd}$ were the lowest and intermediate, respectively, in the bentonite amended soils. In general, the removal capacity of bentonite for $\mathrm{Ni}$ was higher than $\mathrm{Co}$ and $\mathrm{Cd}$ over the studied incubation periods. It is noticed that the removal capacity of bentonite for Co was almost similar over all the incubation periods.

Key words: Organic remediation, polluted soil with heavy metals, poultry manure, compost and bentonite as soil amendments

Fayoum J. Agric. Res. \& Dev., Vol.22, No.1, January, 2008 
INTRODUCTION:

Rapid industrialization and urbanization in last century due to enormous technological innovations have led to the problem of environmental pollution and ecological concerns. Heavy metal contamination of soil environment has been occurring for centuries, but its extent has increased markedly in the last fifty years due to technological developments. In recent years, widespread concern has arisen over the implications of human health problems from increasing heavy metals in soils (Majid and Argue, 2001; Zhou, 2003). The remained heavy metals in various ecosystems would seep into ground water or even channel into the food chain by crops growing on such a soil (Lin et al.,1998). These heavy metals may adversely affect the soil ecosystem safety, not only agricultural product and water quality, but also the human health (Adriano, 2001; Zhou $\boldsymbol{e t}$ al., 2004).

The term heavy metal is widely used although others such as toxic metals, potentially toxic elements and trace elements are possible alternatives. These elements are referred to be as essential trace elements or micronutrient elements. Heavy metals are elements that have metallic properties, atomic number over 20 (Nieboer and Richardson, 1980) and a density higher than $5.0 \mathrm{~g} / \mathrm{cm}^{3}$ (Sanita di Toppi and Gabbrielli, 1999).

Heavy metals are released to the environment by a very wide variety of industrial and domestic activities, metal-rich mine tailings, metal smelting, electroplating, gas exhausts, energy and fuel production, downwash from power lines, intensive agriculture, and some sludge dumping are the most important human activities that contaminate soils and aqueous streams with large quantities of toxic metals (Seaward and Richardson, 1990 and Harrison, 1996). The environmental problems associated with pollution with heavy metals have adverse effects on plant and may cause either evolutionary or drastic changes even over short periods of time (Kabata-Pendias and Pendias, 1992). Heavy metals, even at trace concentration, can cause serious problems to all organisms and heavy metal bioaccumulation in the food chain can be highly dangerous (Sanita di Toppi and Gabbrielli, 1999).

The human influence is amply manifested by the elevated levels of trace metals now found in soils in urban areas, around industrial installations, in agricultural soils, in forest soils and downwind of industrialized areas (Adriano, 1988). Diels et al. (2002) mentioned that in situ application of soil additives modifying the physicochemical properties of the contaminating heavy metals combined with the development of biological communities and plants for further metal immobilization was shown to be a very promising alternative remediation method based on risk reduction and time and cost efficiency. Shuman (1999) indicated that solid organic matter adsorbed heavy metal by physical and chemical adsorption and for soluble organic matter that complexed heavy metal in solution. Yuan and Lavkulich (1997) reported that the adsorption capacity of soil for $\mathrm{Zn}$ was reduced by $72 \%$, when $11 \%$ of the organic $\mathrm{C}$ content was lost.

The current study deals with the effect of three different soil amendments on immobilization of some heavy metal ions (i.e., $\mathrm{Ni}$, $\mathrm{Co}$ and $\mathrm{Cd}$ ) in contaminated soils resulted from some anthropogenic activities.

\section{MATERILAS AND METHODS:}

An incubation pot experiment was conducted on two contaminated soils with some heavy metals (i.e., Ni, Co and Cd) collected from El-Gabal El-Asfar farm (Qalubia Governorate) and Arab Abu Said village, El-Saff distict (Giza

Fayoum J. Agric. Res. \& Dev., Vol.22, No.1, January, 2008 
Governorate), which are irrigated with sewage effluent and industrial-wastes, respectively. Three organic and inorganic soil amendments, i.e., poultry manure, organic compost and bentonite were used for immobilizing the studied heavy metals in both soils under investigation. Some physical and chemical properties of the studied soils and soil amendments are presented in Table (1).

\section{The incubation pot experiment:}

Each of the two investigated soils was thoroughly mixed with the tested three soil amendments (i.e., poultry manure, organic compost and bentonite) at a rate of $2 \%$, then packed in plastic pots of $200 \mathrm{~g}$ soil capacity, which categorize into three sets prepared for an incubation experiment. The pots were daily wetted with distilled water to reach constant soil moisture content (field capacity) and incubated at room temperature for different incubation periods of $0,25,50$ and 75 days, each treatment was repeated three times. Soil samples were taken from the incubated pots, which representing the different treatments and the different incubation periods, for determining the values of EDTA-extractable Ni, Co and $\mathrm{Cd}$ by using an Atomic Absorption Spectrophotometer (Perkin Elmer, Model 2380).

Laboratory analysis:

* Particle size distribution of the studied soils and bentonite was determined by the pipette method (Piper, 1950).

* Organic matter content was determined according to the modified Walkely and Black's method (Jackson (1973).

* Calcium carbonate was determined by using Collin's Calcimeter (Wright, 1939).

* Soil pH was determined in 1:2.5 soil or amendment water suspension as described by Page et al. (1982).

* ECe and soluble anions ions were determined in soil paste extract according to Jackson (1973).

* Cation exchange capacity of soil (CEC) was determined according to the method outlined by Jackson (1973).

* Organic amendments were wet digested for determining the contents of N, P and $\mathrm{K}$ according to the methods outlined by Chapman and Pratt (1961).

* Available contents of $\mathrm{Ni}, \mathrm{Co}$ and $\mathrm{Cd}$ were extracted with EDTA solution (Soltanpour and Schwab, 1977), and determined by using an Atomic Absorption Spectrophotometer (Perkin Elmer, Model 2380).

Fayoum J. Agric. Res. \& Dev., Vol.22, No.1, January, 2008 
Ibrahim M.A. Hegazi, et al.

Table (1): The main physical and chemical properties of the studied soils and soil amendments.

\begin{tabular}{|c|c|c|c|c|c|}
\hline \multirow[b]{2}{*}{ Properties } & \multicolumn{2}{|c|}{ Investigated soils } & \multicolumn{3}{|c|}{ Investigated soil amendment } \\
\hline & $\begin{array}{c}\text { El-Gabal } \\
\text { El-Asfar } \\
\text { soil } \\
\end{array}$ & El-Saff & Bentonite & $\begin{array}{l}\text { Organic } \\
\text { compost }\end{array}$ & $\begin{array}{l}\text { Poultry } \\
\text { manure }\end{array}$ \\
\hline \multicolumn{6}{|l|}{ Particle size distribution \%: } \\
\hline Coarse sand & 49.00 & 60.39 & 0.50 & & \\
\hline Fine sand & 19.20 & 27.50 & 4.50 & & \\
\hline Silt & 23.20 & 8.17 & 23.10 & & \\
\hline Clay & 8.60 & 3.94 & 71.90 & & \\
\hline Textural class & Sandy loam & Sandy & Clay & & \\
\hline $\mathrm{EC}(\mathrm{dS} / \mathrm{m})$ & 4.10 & 6.70 & 2.15 & 3.18 & 2.36 \\
\hline \multicolumn{6}{|l|}{ Soluble cations $\left(\mathrm{mmol}_{c} \mathrm{~L}^{-1}\right)$ : } \\
\hline $\mathrm{Ca}^{2+}$ & 17.20 & 35.80 & 1.53 & & \\
\hline $\mathrm{Mg}^{2+}$ & 16.20 & 15.00 & 2.26 & & \\
\hline $\mathrm{Na}^{+}$ & 9.50 & 18.50 & 14.9 & & \\
\hline $\mathrm{K}^{+}$ & 0.98 & 2.50 & 0.22 & & \\
\hline \multicolumn{6}{|l|}{ Soluble anions $\left(\mathrm{mmol}_{c} L^{-1}\right)$ : } \\
\hline $\mathrm{CO}_{3}{ }^{2-}$ & & & & & \\
\hline $\mathrm{HCO}_{3-}{ }^{-}$ & 6.90 & 3.00 & 2.7 & & \\
\hline $\mathrm{Cl}^{-}$ & 20.20 & 35.00 & 15.36 & & \\
\hline $\mathrm{SO}_{4}{ }^{2-}$ & 16.78 & 33.80 & 0.85 & & \\
\hline \multicolumn{6}{|c|}{ Available heavy metals $\left(\mathrm{mg} \mathrm{kg}^{-1}\right)$ : } \\
\hline $\mathrm{Cd}$ & 0.334 & 0.306 & 0.015 & 0.020 & 0.024 \\
\hline $\mathrm{Co}$ & 0.182 & 0.126 & 0.060 & 0.036 & 0.054 \\
\hline $\mathrm{Ni}$ & 4.116 & 1.305 & 0.014 & 0.257 & 0.224 \\
\hline $\mathrm{pH}(1: 2.5$ soil suspension $)$ & 6.05 & 7.80 & 7.68 & 7.60 & 6.50 \\
\hline $\mathrm{CaCO}_{3} \%$ & 0.39 & 12.45 & 1.50 & & \\
\hline $\mathrm{CEC}\left(\mathrm{cmol}_{\mathrm{c}} \mathrm{kg}^{-1}\right)$ & 12.65 & 5.72 & 51.96 & 509.78 & 490.98 \\
\hline Organic matter $\%$ & 3.90 & 0.94 & 0.12 & 43.27 & 55.47 \\
\hline Organic carbon $\%$ & & & & 25.16 & 32.25 \\
\hline Total N \% & & & & 1.80 & 2.15 \\
\hline Total P \% & & & & 0.77 & 0.90 \\
\hline Total K \% & & & & 3.13 & 3.35 \\
\hline $\mathrm{C} / \mathrm{N}$ ratio & & & & 13.98 & 15.00 \\
\hline
\end{tabular}

RESULTS AND DISCUSSION:

EDTPA-extractable heavy metal ions as affected by the applied different soil amendments:

\section{Poultry manure:}

Data presented in Table (2) show the positive effect of applied poultry manure as an amendment on EDTA-extractable Ni, Co and Cd from both soils under investigation. Also, data reveal the effect of contact time of the applied poultry manure on adsorbed amounts and sorption percentages of the concerned metal ions besides the removal capacity of the poultry manure for these metals.

Fayoum J. Agric. Res. \& Dev., Vol.22, No.1, January, 2008 
ORGANIC AND INORGANIC REMEDIATIONS OF CONTAMINA...

Table (2): Effect of applied poultry manure on EDTA-extractable metal ions and their sorption parameters for both the studied two soils.

\begin{tabular}{|c|c|c|c|c|c|c|c|}
\hline \multirow{2}{*}{$\begin{array}{l}\text { Sorption } \\
\text { parameter }\end{array}$} & \multirow{2}{*}{$\begin{array}{c}\text { Incubation } \\
\text { period }\end{array}$} & \multicolumn{3}{|c|}{ El-Gabal El-Asfar soil } & \multicolumn{3}{|c|}{ El-Saff soil } \\
\hline & & $\mathrm{Ni}$ & $\mathrm{Co}$ & $\mathrm{Ni}$ & $\mathrm{Co}$ & $\mathrm{Ni}$ & Co \\
\hline \multirow{4}{*}{$\begin{array}{l}\text { Residual } \\
\text { amount } \\
\left(\mathrm{mg} \mathrm{kg}^{-1}\right)\end{array}$} & 0 & 4.123 & 0.101 & 0.339 & 1.370 & 0.142 & 0.309 \\
\hline & 25 & 32.16 & 0.076 & 0.281 & 1.027 & 0.105 & 0.250 \\
\hline & 50 & 2.846 & 0.065 & 0.254 & 0.890 & 0.089 & 0.227 \\
\hline & 75 & 2.556 & 0.057 & 0.235 & 0.822 & 0.081 & 0.210 \\
\hline \multirow{3}{*}{$\begin{array}{l}\text { Sorbet amount } \\
\quad\left(\mathrm{mg} \mathrm{kg}^{-1}\right)\end{array}$} & 25 & 0.907 & 0.025 & 0.058 & 0.343 & 0.037 & 0.059 \\
\hline & 50 & 1.277 & 0.036 & 0.085 & 0.480 & 0.053 & 0.082 \\
\hline & 75 & 1.567 & 0.044 & 0.104 & 0.548 & 0.061 & 0.099 \\
\hline \multirow{3}{*}{$\begin{array}{c}\text { Sorbet amount } \\
(\%)\end{array}$} & 25 & 21.99 & 24.75 & 17.10 & 25.03 & 26.05 & 19.09 \\
\hline & 50 & 30.97 & 35.64 & 25.07 & 35.03 & 37.32 & 26.53 \\
\hline & 75 & 38.00 & 43.56 & 30.67 & 40.00 & 42.95 & 32.03 \\
\hline \multirow{3}{*}{$\begin{array}{c}\text { Removal } \\
\text { capacity } \\
\left(\mathrm{mg} \mathrm{metal} \mathrm{g}^{-1}\right) \\
\end{array}$} & 25 & 0.045 & 0.001 & 0.003 & 0.017 & 0.002 & 0.003 \\
\hline & 50 & 0.064 & 0.002 & 0.004 & 0.024 & 0.003 & 0.004 \\
\hline & 75 & 0.078 & 0.002 & 0.005 & 0.27 & 0.003 & 0.005 \\
\hline
\end{tabular}

The obtained data indicate that the EDTA-extractable amounts of $\mathrm{Ni}$, Co and $\mathrm{Cd}$ tended to decrease as a result of applied poultry manure, with a more effective role with increasing time of contact between the applied amendment and the investigated soil. The values of EDTA-extractable $\mathrm{Ni}$ and $\mathrm{Cd}$ were higher in El-Gabal El-Asfar soil (non-calcareous) than in El-Saff one (calcareous), whereas the reverse was true for EDTA-extractable Co. Moreover the adsorbed values of $\mathrm{Ni}, \mathrm{Co}$ and $\mathrm{Cd}$ increased progressively with period of incubation. This trend was occurred over all the investigated incubation periods. Similar results reported by Badr (2005) for Cd and Ismail (2007) for both $\mathrm{Ni}$ and Co.

The effect of the poultry manure on sorption of $\mathrm{Ni}, \mathrm{Co}$ and $\mathrm{Cd}$ metal ions from soil may be attributed to the presence of both $\mathrm{COOH}$ and phenolic-OH groups in the humic and fulvic acids released during the decomposition of poultry manure. These functional groups are capable of exerting a variety of reactions, including electrostatic bonding, co-adsorption, complex formation and chelation reactions. In the formation of chelates, the metal ions may connect itself to one or more radicals. The radicals involved may belong to the same or different organic ligends. Also, Tan (1993) reported that the organic acids formed due to decomposition of the organic matter bind excessive metal ions in the soil and later release them in smaller amounts. In this way, $\mathrm{Ni}, \mathrm{Co}$ and $\mathrm{Cd}$ toxicity can be controlled because the organic acids prevent buildup of large amounts of available trace metal in soil. Many of the organometal chelates formed are insoluble and prevent the metal from reaching ground water. The later process is an important aspect in environmental quality.

The relative efficiency for the poultry manure amended soils in removing the studied metal ions was highest with $\mathrm{Co}$, lowest with $\mathrm{Cd}$ and intermediate with $\mathrm{Ni}$. In this concern, Cast (1976) reported that, generally, ions with smaller hydrated sizes are preferably adsorbed. The values of the removal capacity of the poultry manure were seemed to be the highest with $\mathrm{Ni}$, lowest with $\mathrm{Co}$ and intermediate for $\mathrm{Cd}$ although they were closer to those of $\mathrm{Co}$ than the corresponding ones of $\mathrm{Ni}$. The higher removal capacity of the poultry manure for $\mathrm{Ni}$ is probably due to its association with $\mathrm{O}^{-}$and $\mathrm{OH}^{-}$ligands. Accordingly, it can

Fayoum J. Agric. Res. \& Dev., Vol.22, No.1, January, 2008 
be deduced that the removal of the metal ions from the investigated soils by poultry manure as organic material is an important mechanism that controls metal concentration in aqueous system since about $80 \%$ of the organic material consists of humic substances which provide important sources of the adsorbent organic ligands, and therefore they are expected to reduce the availability of metal ions in aquatic systems (Liu and Gonzalez, 1999).

The values of removal capacity of poultry manure for the studied metal ions were generally higher in El-Gabal El-Asfar poultry manure amended soil than in El-Saff poultry manure amended soil. Such a variation can be attributed mainly to the initial higher values of EDTA-extractable metal ions in El-Gabal El-Asfar soil than El-Saff soil. Moreover, the original organic matter content of El-Gabal El-Asfar soil is higher than that of El-Saff soil which means providing more organic ligands for complexing the metal ions in the former soil than the latter one. These findings emphasized by both Badr (2005) and Ismail (2007) who reported that organic matter is considered an important factor for $\mathrm{Ni}$, Co and Cd removal from soil.

\section{Organic compost:}

Effects of compost on the amounts of EDTA-extractable Ni, Co and Cd as well as their sorption parameters are shown in Table (3).

Table (3): Effect of applied organic compost on EDTA-extractable metal ions and their sorption parameters for both the studied two soils.

\begin{tabular}{|c|c|c|c|c|c|c|c|}
\hline \multirow{2}{*}{$\begin{array}{l}\text { Sorption } \\
\text { parameter }\end{array}$} & \multirow{2}{*}{$\begin{array}{c}\text { Incubation } \\
\text { period }\end{array}$} & \multicolumn{3}{|c|}{ El-Gabal El-Asfar soil } & \multicolumn{3}{|c|}{ El-Saff soil } \\
\hline & & $\mathrm{Ni}$ & $\mathrm{Co}$ & $\mathrm{Ni}$ & $\mathrm{Co}$ & $\mathrm{Ni}$ & $\mathrm{Co}$ \\
\hline \multirow{4}{*}{$\begin{array}{l}\text { Residual } \\
\text { amount } \\
\left(\mathrm{mg} \mathrm{kg}^{-1}\right)\end{array}$} & 0 & 4.086 & 0.083 & 0.333 & 1.328 & 0.127 & 0.304 \\
\hline & 25 & 3.432 & 0.068 & 0.299 & 1.062 & 0.099 & 0.268 \\
\hline & 50 & 3.187 & 0.062 & 0.248 & 0.982 & 0.091 & 0.254 \\
\hline & 75 & 3.023 & 0.058 & 0.269 & 0.942 & 0.087 & 0.235 \\
\hline \multirow{3}{*}{$\begin{array}{l}\text { Sorbet amount } \\
\qquad\left(\mathrm{mg} \mathrm{kg}^{-1}\right)\end{array}$} & 25 & 0.654 & 0.015 & 0.034 & 0.266 & 0.028 & 0.036 \\
\hline & 50 & 0.899 & 0.021 & 0.085 & 0.346 & 0.036 & 0.050 \\
\hline & 75 & 1.063 & 0.025 & 0.064 & 0.386 & 0.040 & 0.069 \\
\hline \multirow{3}{*}{$\begin{array}{c}\text { Sorbet amount } \\
(\%)\end{array}$} & 25 & 16.00 & 18.07 & 10.21 & 20.03 & 22.04 & 11.84 \\
\hline & 50 & 22.00 & 25.30 & 25.52 & 26.05 & 28.34 & 16.44 \\
\hline & 75 & 26.01 & 30.12 & 19.21 & 29.06 & 31.49 & 22.69 \\
\hline \multirow{3}{*}{$\begin{array}{c}\text { Removal } \\
\text { capacity } \\
\left(\mathrm{mg} \mathrm{metal} \mathrm{g}^{-1}\right)\end{array}$} & 25 & 0.033 & 0.001 & 0.002 & 0.013 & 0.001 & 0.002 \\
\hline & 50 & 0.045 & 0.001 & 0.004 & 0.017 & 0.002 & 0.003 \\
\hline & 75 & 0.053 & 0.001 & 0.003 & 0.019 & 0.002 & 0.003 \\
\hline
\end{tabular}

Results reveal that application of compost to both El-Gabal El-Asfar (noncalcareous) and El-Saff soils (calcareous) could minimize or immobilize the values of EDTA-xtractable $\mathrm{Ni}$, Co and $\mathrm{Cd}$ in situ. These results are in well agreement with those obtained by Takamatsu and Yashida (1978) who pointed out that organic amendments such as organic compost contains a high proportion of organic matter can decrease the availability of heavy metals in soils by adsorption and by forming stable complexes with humic substances. The humic substances consist of a heterogeneous mixture of interacting functional groups, which include strong acidic (sulfonic acid- $\mathrm{SO}_{2} \mathrm{OH}$ ), weak acidic (carboxyl$\mathrm{COOH}$, hydroxyl-OH) as well as carbonyl $(-\mathrm{C}=\mathrm{O})$ and amine $\left(-\mathrm{NH}_{2}\right)$ groups. These organic ligands form relatively weak complexes through either cation exchange capacity or strongly bound inner-sphere complexes (Sposito, 1984).

Fayoum J. Agric. Res. \& Dev., Vol.22, No.1, January, 2008 
Evangelou et al. (1999) reported that metal ions formed stronger complexes with humic fraction that contained more carboxylic groups. Senesi and Sakellariadout (1997) reported that humic substances may interact in several ways with metal ions including ion exchange, complexation, adsorption \& desorption, precipitation and dissolution, thus affecting several physical and chemical properties of metal ions including their oxidation state and chemical form, apparent solubility, phase distribution and speciation. These conditions will influence the metal mobility and transport, immobilization and geoaccumulation. Also, Kaschl $\boldsymbol{e t}$ al. (2002) found that $\mathrm{N}$-containing groups in organic matter interacted strongly with the trace metal ions.

The effect of organic compost on reducing the amounts of EDTAextractable metal ions seemed more pronounced by prolonging period of incubation between the organic substances and both the investigated calcareous and non-calcareous soils, yet such an effect seemed more obvious in the noncalcareous soil than the calcareous one. Accordingly, it was found that adsorbed amounts of $\mathrm{Ni}, \mathrm{Co}$ and $\mathrm{Cd}$ in El-Gabal El-Asfar soil exceeded obviously the corresponding adsorbed amounts of these metal ions in El-Saff soil. On the other hand, the sorption or removal percentages of the concerned metal ions in the calcareous soil of El-Saff exceeded obviously the corresponding sorption percentages of the noncalcareous soil of El-Gabal El-Asfar, where $\mathrm{CaCO}_{3}$ of the former soil might enhance the sorption effect of the applied compost for $\mathrm{Ni}$, Co and $\mathrm{Cd}$. Moreover, the higher $\mathrm{pH}$ value of El-Saff soil is thought increase the $\mathrm{pH}$ - dependent charge of the soil minerals as well as that of the organic colloids (humic substance in the mature sewage) and hence increases the ability of this soil to adsorb more mineral ions (Spark et al., 1995 a \& b). The adsorbed amounts of the concerned metal ions were increased with prolonging the period of incubation between organic compost and the investigated soils.

Removal capacity of the compost for $\mathrm{Ni}$, Co and Cd was obviously of higher values in the non-calcareous soil of El-Gabal El-Asfar than in the calcareous one of El-Saff. Such a result may be attributed to the higher amounts of EDTA- extractable metal ions found primarily in El-Gabal El-Asfar soil than in El- Saff soil, and hence the effect of the applied compost on removal of the studied heavy metals from the former soil seemed more pronounced.

\section{Bentonite:}

Data presented in Table (4) reveal that values of EDTA-extractable Ni, Co and Cd from both El-Gabal El-Asfar and El-Saff soils tended to decrease with increasing time of incubation period between soil and bentonite. Also, it is observed that the rate of reduction in EDTA-extractable $\mathrm{Ni}$, Co and $\mathrm{Cd}$ tended to decline as incubation period progressed. These results stand in well agreement with those of Usman et al. (2004) who concluded that the addition of clay minerals, especially bentonite, decreased the extractability of heavy metals during incubation. Consequently, it was found that values of sorbed $\mathrm{Ni}$, Co and $\mathrm{Cd}$ increased in both the investigated soils with increasing time of incubation period between the investigated soils and bentonite. The reduction in EDTAextractable $\mathrm{Ni}, \mathrm{Co}$ and $\mathrm{Cd}$ can be explained by their sorption or retention by bentionte-amended soils.

Fayoum J. Agric. Res. \& Dev., Vol.22, No.1, January, 2008 
Table (4): Effect of applied bentonite on EDTA-extractable metal ions and their sorption parameters for both the studied two soils.

\begin{tabular}{|c|c|c|c|c|c|c|c|}
\hline \multirow{2}{*}{$\begin{array}{l}\text { Sorption } \\
\text { parameter }\end{array}$} & \multirow{2}{*}{$\begin{array}{c}\text { Incubation } \\
\text { period }\end{array}$} & \multicolumn{3}{|c|}{ El-Gabal El-Asfar soil } & \multicolumn{3}{|c|}{ El-Saff soil } \\
\hline & & $\mathrm{Ni}$ & $\mathrm{Co}$ & $\mathrm{Ni}$ & $\mathrm{Co}$ & $\mathrm{Ni}$ & Co \\
\hline \multirow{4}{*}{$\begin{array}{l}\text { Residual } \\
\text { amount } \\
\left(\mathrm{mg} \mathrm{kg}^{-1}\right)\end{array}$} & 0 & 4.038 & 0.078 & 0.333 & 1.282 & 0.123 & 0.304 \\
\hline & 25 & 3.553 & 0.067 & 0.306 & 1.076 & 0.100 & 0.276 \\
\hline & 50 & 3.392 & 0.064 & 0.296 & 1.038 & 0.096 & 0.264 \\
\hline & 75 & 3.230 & 0.060 & 0.089 & 0.974 & 0.089 & 0.246 \\
\hline \multirow{3}{*}{$\begin{array}{l}\text { Sorbet amount } \\
\quad\left(\mathrm{mg} \mathrm{kg}^{-1}\right)\end{array}$} & 25 & 0.485 & 0.011 & 0.027 & 0.206 & 0.023 & 0.028 \\
\hline & 50 & 0.646 & 0.014 & 0.037 & 0.244 & 0.027 & 0.040 \\
\hline & 75 & 0.808 & 0.018 & 0.244 & 0.308 & 0.034 & 0.058 \\
\hline \multirow{3}{*}{$\begin{array}{c}\text { Sorbet amount } \\
(\%)\end{array}$} & 25 & 12.01 & 14.10 & 8.11 & 16.06 & 18.69 & 9.21 \\
\hline & 50 & 15.99 & 17.94 & 11.11 & 19.03 & 21.95 & 13.15 \\
\hline & 75 & 20.01 & 23.07 & 13.27 & 24.02 & 27.64 & 19.07 \\
\hline \multirow{3}{*}{$\begin{array}{c}\text { Removal } \\
\text { capacity } \\
\left(\mathrm{mg} \mathrm{metal} \mathrm{g}^{-1}\right)\end{array}$} & 25 & 0.024 & 0.001 & 0.001 & 0.010 & 0.001 & 0.001 \\
\hline & 50 & 0.032 & 0.001 & 0.002 & 0.012 & 0.001 & 0.002 \\
\hline & 75 & 0.040 & 0.001 & 0.012 & 0.015 & 0.002 & 0.003 \\
\hline
\end{tabular}

Ayari et al. (2005) reported that sorption reactions involve adsorption of metal-ions on the solid-solution interface, precipitation and polymeristion. Faust and Aly (1987) reported that adsorption of metals at the mineral- water interface is often initially fast followed by a decrease in the adsorption rate. Sparks (1995) revealed that adsorption is much faster process than precipitation. Moreover, Ayari et al. (2007) reported that there are two types of reactions necessary to explain ion adsorption on clay surfaces. The first one is a cation-exchange mechanism that occurs on the interlayer and basal planes. It originates from the presence of a permanent negative structural charge in the alumina silicate layer created by isomorphous substitution in the latter. The quantity of exchange sites can be derived from the structural formula, and it is compensated by "exchangeable cations" that generally form outer sphere gٔomplexes with siloxane cavities (Sposito, 1981 and 1984). The second type of reaction is the $\mathrm{pH}$-dependent specific sorption on the clay minerals edges (Baeyens and Bradbury, 1997 and Fletcher and Sposito, 1989).

Absolute values of sorbed $\mathrm{Ni}$ were the highest over the all periods of incubation, whereas those of the corresponding sorbed ones of Co were the lowest and those of sorbed $\mathrm{Cd}$ were intermediate although they were more nearer to those of $\mathrm{Co}$ than those of $\mathrm{Ni}$. On other words, the metal sorbed onto bentonite-amended soils varied in the following descending order: $\mathrm{Ni}>\mathrm{Cd}>$ Co. However, sorption percentages of Co were shown to be highest within the first and second periods of incubation (i.e. after 25 and 50 days) in El-Gabal ElAsfar soil amended with bentoniete and over the whole period of incubation in El-Saff soil amended with bentoniete. The percentage of $\mathrm{Cd}$ sorbed on the bentonit amended soil of El-Gabal El-Asfar seemed lowest values after 25 and 50 days of incubation. Likewise, the percentage values of $\mathrm{Cd}$ sorbed on the bentonite-amended soil of El-Saff were shown to be lowest over the whole periods of incubation. Meanwhile, sorption percentage of $\mathrm{Ni}$ showed intermediate values over the whole periods of incubation for El-Saff soil with bentonite as well as the first and second periods of incubating El-Gabal El-Asfar soil with it, however, the third period of incubation was characterized by the lowest sorption percentage of $\mathrm{Ni}$ as compared with the other two studied metal ions of $\mathrm{Cd}$ and $\mathrm{Co}$.

Fayoum J. Agric. Res. \& Dev., Vol.22, No.1, January, 2008 
The aforementioned results may lead to conclude that percentages of the metal ions sorbed on the bentonite-amended soils might follow a trend quite that shown by their sorbed amounts. For example, the studied metal ions could be arranged according to their sorbed amounts on both the investigated soils in the following descending order: $\mathrm{Ni}>\mathrm{Cd}>\mathrm{Co}$, whereas they followed the descending sequence: $\mathrm{Co}>\mathrm{Ni}>\mathrm{Cd}$ according to their sorption percentages over the whole incubation periods of El-Saff soil and both the first and second incubation periods of El-Gabal El-Asfar soil. The third incubation period of ElGabal El-Asfar soil with bentonite was characterized by the following descending order for the studied metal ions according to their sorption percentages: $\mathrm{Cd}>\mathrm{Co}>\mathrm{Ni}$.

Data presented in Table (2) reveal that removal capacity of the bentonite varied according to type of the metal ion itself as well as type of the investigated soil. In this concern, the bentonite showed the highest removal capacity for $\mathrm{Ni}$, whereas its capacity for removing $\mathrm{Cd}$ and $\mathrm{Co}$ were far lower than the corresponding ones of $\mathrm{Ni}$ over the different studied incubation periods, which were characterized, generally, by increasing the removal capacity by progressing time. Yet, it is worthy to indicate that removal capacity of bentonite for $\mathrm{Co}$ remained almost constant over the different periods of incubation. The abundance of bentonite and its low cost are likely to make it a strong candidate as an adsorbant for the removal of heavy metals from polluted soils.

\section{REFERENCES:}

Adriano, D.C. (1988). Trace elements in the terrestrial environment. SpringerVerlag, New York.

Adriano, D.C. (2001). Trace Elements in Terrestial Environments; Biogeochemistry, bioavailability and risks of metals. $2^{\text {nd }}$ Ed. Springer, New York, 866 pp.

Ayari, F.; Srasra, E. and Trabelsi-Ayadi, M. (2005). Characterization of bentonitic clay and their use as adsorbent. Desalination, 185: 391-397.

Ayari, F.; Sraera, E. and Trabelsi-Ayadi, M. (2007). Retention of lead from an aqueous solution by use of bentonite as adsorbent for reducing leading from industrial effecctents. Desalination, 206: 270-278.

Badr, R.A.M. (2005). Retention and release of some heavy metals in polluted soils. $\mathrm{Ph}$. D. Thesis, Fac. of Agric., Benha Univ., Egypt.

Baeyens, B. and Bradbury, M.H. (1997). A mechanistic description of $\mathrm{Ni}$ and $\mathrm{Zn}$ sorption on Na-montmorillonitic. Part 1: Titration and sorption measurements .J. Contam. Hydrol., 27: 199-222.

Cast, N.G. (1976). Application of sewage sludge to cropland. Appraisal of potential hazards of the heavy metals to plants and animals. Office of Water Program Operations, EPA. Washington, D.C., Report No. 64.EPA.

Chapman, H.D. and Pratt, P.F. (1961). Methods of Analysis for Soils, Plants and Waters. Univ. of California, Riverside, U.S.A.

Diels, L.; Van der Lelie, N. and Bastiaens, L. (2002). New development of heavy metal contaminated soils. Rev.Environ.Sci.Bio/Technol., 1: 75-82.

Evangelou, V.P.; Marsi, M. and Vandiviere, M.M. (1999). Stability of $\mathrm{Ca}^{2+}, \mathrm{Cd}^{2+}$, $\mathrm{Cu}^{2+}$, illite-humic complexes and $\mathrm{pH}$ influences. Plant and Soil, 213: 63-74.

Faust, S.D. and Aly, O.M. (1987). Adsorption processes for water treatment. Butterwort Publishers, Boston, 108-113 pp.

Fletcher, P. and Sposito, G. (1989). The chemical modeling of clay/elctrolyte interactions for montmorillonite. Clay Minerals, 24: 375 -391.

Harrison, R.M. (1996). Pollution Causes; Effect and Control. $3^{\text {rd }}$ Ed., The Royal Society of Chemistry, pp.479.

Fayoum J. Agric. Res. \& Dev., Vol.22, No.1, January, 2008 
Ismail, A.O.A.(2007). Factors governing chemical behaviour of some trace elements in soil. Ph. D. Thesis, Fac. of Agric., Beha Univ.

Jackson, M.L. (1973). Soil Chemical Analysis. Prentice Hall of India Private LTD, New York.

Kabata-Pendias, A. and Pendias, H. (1992). Trace Elements in Soils and Plants. $2^{\text {nd }}$ Ed., CRC Press, Inc. Boca Raton Ann. Arbor, London.

Kaschl, A.; Romheld,V. and Chen, Y.(2002). Cadmium binding by fraction of dissolved organic mater and humic substance from municipal solid waste compost. J. Environ. Qual., 31: 1885-1892.

Lin, C.F.; S.S. Lo; H.Y. Lin and Y.C. Lee (1998). Stabilization of cadmium contaminated soils using synthesized zeolite. J. Hazard. Mat., 60: 217-226.

Liu, A. and Gonzalez, R.D. (1999). Adsorption/desorption in a systemic consisting of humic acid, heavy metals and clay minerals. J. Colloid Interface Sci., 218: 225-232.

Majid, A. and Argue, S. (2001). Remediation of heavy metal contaminated solid wastes using agglomeration techniques. Minerals Eng., 14 (11): 1513-1525.

Nieboer, E. and Richardson, D.H.S. (1980). The replacement of the nondescript term heavy metals by a biologically and chemically significant classification of metal ions. Environ. Pollution, 1: 3-26.

Page, A.L.; Miller, R.H. and .Kenney, D.R. (1982). Methods of Soil Analysis. Part 2: Chemical and Microbiological Proprieties. $2^{\text {nd }}$ Ed., American Society of Agronomy Inc., Madison, Wisconsin, USA.

Piper, C.S. (1950). Soil and Plant Analysis. Inter. Sci. Publisher Inc., New York, USA.

Sanita, di Toppi, L. and Gabbrielli, R. (1999). Response to cadmium in higher plants. Environ. and Exper. Botany, 41:105-130.

Saxena, S. and D'Souza, S.F. (2005). Heavy metal pollution abatement using rock phosphate mineral. Founder's Day Special Issue.

Seaward, M.R.D. and Richardson, D.H.S. (1990). Atmospheric sources of meta pollution and effects on vegetation. In: Heavy Metal Tolerance in Plants: Evolutionary Aspects. CRC Press, London, 75-92 pp.

Senesi, N and Sakellariadout, F.(1997). Metal ion complexes in untreated and copper. Reacted humic acids from marine and coastal sediments. In: Biogeochemistry of Trace Metals. Adriano, D.C.; Chem, Z.S.; Yang; S.S. and Iskandar, I.K. (Eds.), Science Reviews, Northwood.

Shuman, L.M. (1999). Organic waste amendments effects on zinc fractions of two soils. J. Environ. Qual., 28: 1447.

Soltanpour, P.N. and Schwab, A.B. (1977). A new soil test for simultaneous extraction of macronutrients in alkaline soils. Comm. Soil Sci. and Plant Annal., 8: 195.

Spark, K.M.; Johnson, B.B. and Wells, J.D. (1995a). Characterizing heavy metal adsorption on oxides and oxyhydroxided. European J. Soil Sci., 46: 621-631.

Spark, K.M.; Wells, J.D. and Johnson, B.B. (1995b). Characterizing trace metal adsorption on Kaolinite. European J. Soil Sci.,46: 633-640.

Sparks, D.L .(1995). Environmental soil chemistry. Academic Press, New York.

Sposito, G. (1981). The operational definition of the zero point of charge in soils. Soil Sci. Soc. Am. J., 45: 292-297.

Sposito, G.(1984). The surface chemistry of soils. Oxford Univ. Press, Oxford, England.

Takamatsu, T.; Yoshida, T. (1978). Determination of stability constants of metalhumic acid complexes by poteniometric titrationand ion-selective electrodes. Soil Sci., 125: 377-386.

Tan,K. H. (1993). Environmental Soil Science. Marcel Dekker, Inc., New York.

Fayoum J. Agric. Res. \& Dev., Vol.22, No.1, January, 2008 
Usman, A.R.A.; Kuzyakov, Y. and Stahr, K. (2004). Effect of clay minerals on extractability of heavy metals and sewage sludge mineralization in soil. Chemistry and Ecology, 20: 1-13.

Wright, C.H. (1939). Soil Analysis. Thomas Murby and Co., London.

Yuan, G. and Lavkulich, L.M. (1997). Sorption Behavior of copper, zinc and cadmium in response to simulated changes in soil properties. Commun. Soil Sci. Plant Anal., 28: 571-587.

Zhou, Q.X. (2003). Interaction between heavy metals and nitrogen fertilizers applied in soil-vegetable system. Bull. Enveiron. Contam. Toxical., 71: 338-344.

Zhou, Q.X.; F.X. Kong and L. Zho (2004). Ecotoxicology. Sci. Press, Beijing, China (in Chinese).

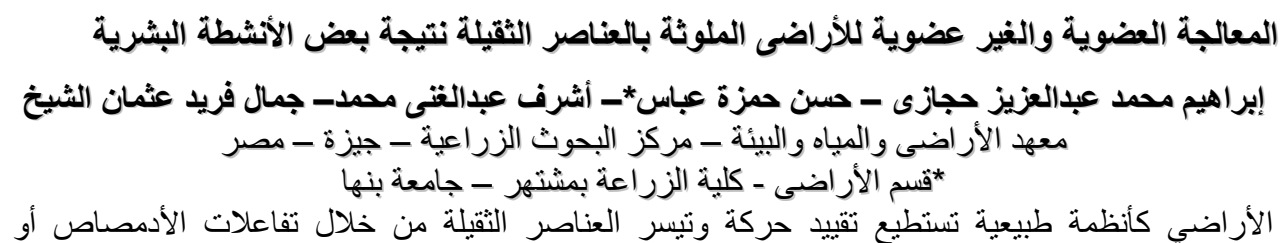

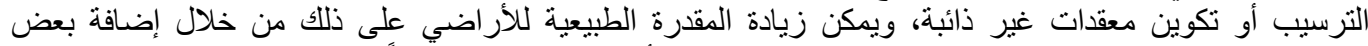

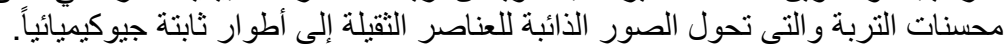

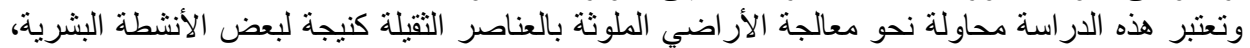

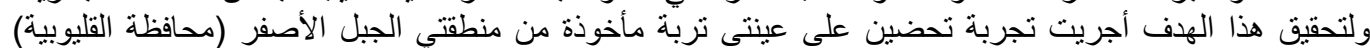

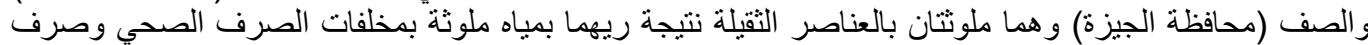

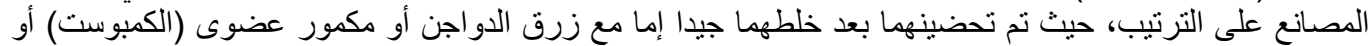

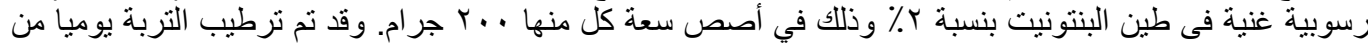

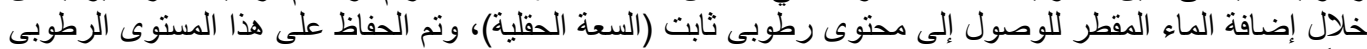

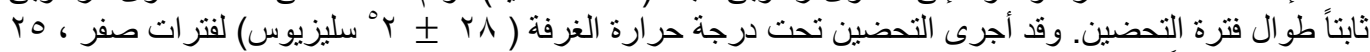

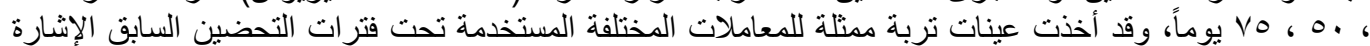

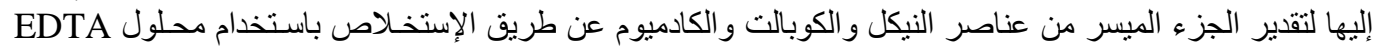

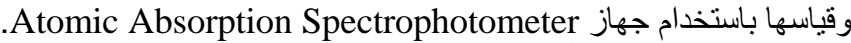
ويمكن تلخيص أهم النتائج التى نم الحصول عليها فئيما فيما يلى :

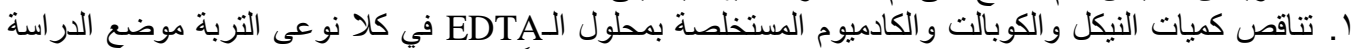

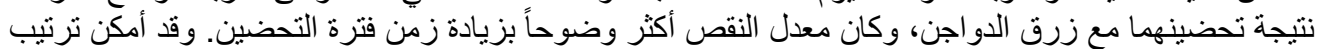

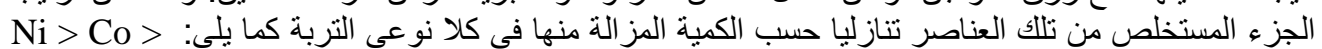

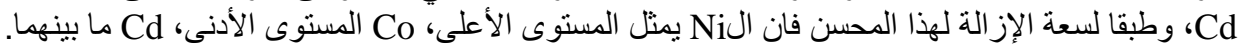

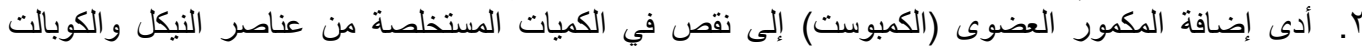

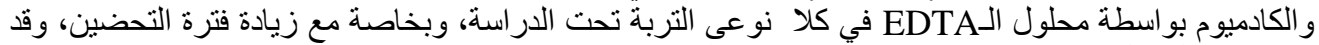

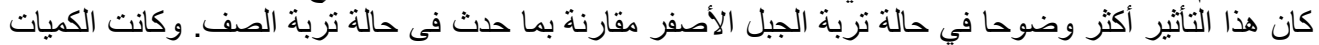

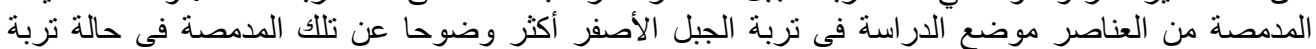

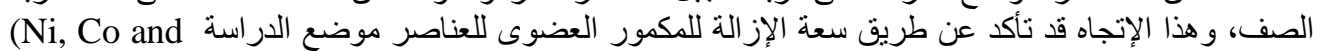

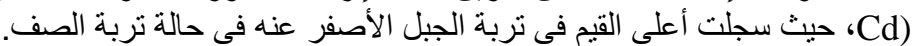

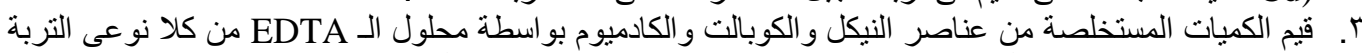

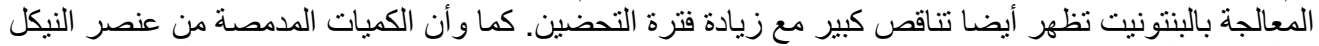

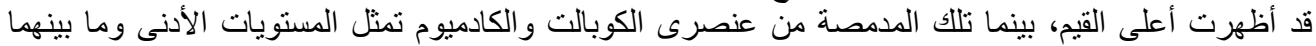

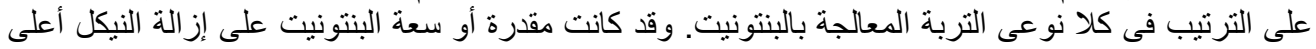

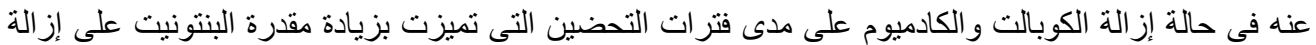

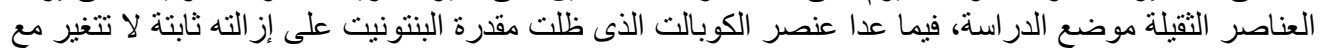
إمتداد فترات التحضين.

Fayoum J. Agric. Res. \& Dev., Vol.22, No.1, January, 2008 